\title{
Evaluation of environmental impact assessment report preparation and public participation in landfill projects in Nepal
}

\author{
Mohan B. Dangi ${ }^{a,}{ }^{*}$, Deanna Fernandez ${ }^{a}$, Upendra B. Bom ${ }^{b}$, Shashidhar Belbase ${ }^{c}$, Rameshwor Kaphle ${ }^{\mathrm{d}}$ \\ a Department of Geography and City \& Regional Planning, California State University, Fresno, USA \\ ${ }^{\mathrm{b}}$ Department of Geography, University of Wyoming, Laramie, USA \\ ${ }^{\mathrm{c}}$ Department of Civil and Architectural Engineering, University of Wyoming, Laramie, USA \\ d Department of Civil and Geomatics Engineering, California State University, Fresno, USA
}

\begin{abstract}
:
This study examined the effectiveness of environmental impact assessment (EIA) in landfill development projects for Kathmandu Valley municipalities in Nepal using a survey, focus group interviews, expert interviews, and observations. The study found that EIA reports are often prepared by incompetent contractors that are not accredited and the reports are poor in quality, too technical, mostly published in the English language, cluttered with irrelevant materials, too long, and frequently contain information copied from other documents. The survey results showed that $66 \%$ of the respondents were unaware of any public meetings conducted for EIA in the current landfill location, $69 \%$ of them were uninformed of any alternate landfill locations, $91 \%$ were unsatisfied with the governmental services provided, and only $14 \%$ were happy with the public participation conducted. Findings from other proposed landfill locations and an old landfill site corroborated that the government fell short in conducting EIA or upholding Nepal's environmental law, thus undercutting public support in such projects. In some cases, retroactive EIA was being conducted to create the appearance that the required procedures were followed, which clearly violated the spirit and elemental principle of the apparatus. In other cases, political parties endorsed EIA in place of public hearings. To rectify flaws in EIA and maintain quality and accepted rigor of EIA in solid waste management (SWM), it is suggested that Nepal devise EIA guidelines for the SWM sector that are more appropriate for local conditions, build institutional capacity, accredit EIA drafters, use alternate methods to notify people about proposed activities, and seek public participation and ownership in the project from the beginning.
\end{abstract}

Keywords:

Environmental impact assessment, Solid waste management, Landfills, Developing countries, Kathmandu, Nepal

\section{Introduction}

Environmental impact assessment (EIA) is a collection of procedures used to formulate decisions and serves as a guide, which offers an orderly, replicable, and cross-disciplinary assessment of possible bio-physical, cultural, social, and economic impacts of a future activity and its reasonable substitutes (INECE, 2013). EIA has been widely used in development projects globally since its inception in the United States in 1970 after the promulgation of National Environmental Policy Act 1969 (NEPA). In the United States, prior to 1970 government departments were largely

\footnotetext{
* Corresponding author. Department of Geography and City \& Regional Planning, California State University, Fresno, 2555 E. San Ramon Avenue, M/S SB69, Fresno, CA 93740, USA. Tel.: p1 559278 4857; fax: p1 559278 7268. Email addresses: mdangi@csufresno.edu,garbagetalk@gmail.com (M.B. Dangi).
}

employing environmental impact measures to minimize any negative effects of federally funded work. A formal debate about environmental preservation and economic development tabled at the United Nations Conference on Environment and Development in 1992 additionally helped the worldwide growth of EIA. As a result more than 100 countries around the world have now adopted EIA (Li, 2008; Wood, 2003). More recently, Morgan (2012) reported that 191 out of the 193 member nations of the United Nations have adopted some sort of EIA policy.

The use of EIA is reasonably recent in Nepal, but its implementation has already raised eyebrows among people from many sectors, including the general public and experts. It has been said that EIA reports are merely rhetoric in Nepal because the reports lack further guidelines and monitoring, fail to win public support, and neglect the development of project alternatives, as well as incompetency, lack of political will and ill preparedness on the part 
of government. Detractors point to the lack of a procedure to accredit report preparers, meaning that anyone could be preparing the reports. In addition, it is not unusual for the text of a report for one project to be copied into a different project's report. Project proponents are often concerned with the size and volume of the report as opposed to its excellence and substance. As a result, many reports contain irrelevant material and misinformation. Critical evaluations of Nepal's EIA system can be found in Anneveldt and Pasman (2001), Belbase (2003), Bhatt and Khanal (2009 and 2010), and Dangi (2009).

A close scrutiny of the environmental assessment steps shown in Fig. 1 points to a possible procedural breakdown in the public participation and scoping of EIA, preparation of EIA, and public inquiry; within public participation and review of EIA; and among public participation, implementation of project, and EIA monitoring and evaluation in Nepal. Also, the available literature lacks any performance evaluation of sectoral EIA in Nepal except a few reports prepared by consultants (GEOCE Consultants, 2009; NESS, 2001), one academic report (Khadka \& Shrestha, 2005), and some country papers (ADB \& ICIMOD, 2006; Anneveldt \& Pasman, 2001). This manuscript intends to fill the void by providing a more rigorous analysis aimed at a scientific audience with a chief emphasis on public participation. Additionally, this paper endeavors to dissect EIA procedures in one particular sector, waste management, to examine the disparity between EIA policy and its application in the field in Nepal. The research utilizes the basic frame outlined by the Environment Protection Act 1996 in Nepal to employ EIA systems and practices in solid waste projects mainly in Kathmandu Valley and proposes an innovative and participatory approach to enhance the usefulness of the instrument in Nepal and other developing areas. By focusing on one sector, the research can delve into the real defects of the EIA tool. Also, dissecting solid waste management (SWM), which is still growing and has been prioritized as one of the five major environmental problems in Nepal, will better present an evaluation of the shortcomings of the current EIA procedures, areas where waste management could benefit from government agencies' interpretation of the legislation, resources allocation to recruit experts to prepare EIA reports, and methods to make the process more responsive to the public and accountable to taxpayers.

\section{Evolution of EIA in Nepal}

Nepal formally adopted EIA in 1993. While Nepal's drive for modernization dates back to the country's First Five Year Plan of 1956-61, environmental issues were not discussed as part of the planning process until the Sixth Five Year Plan (1980-85) that called for the integration of EIA in the expansion of a facility for the Department of Soil Conservation (Bhatt \& Khanal, 2010). EIA was introduced into sector wide development, primarily in improvement of hydropower projects, irrigation, drinking water, and road construction in the 1980s and early 1990s (Belbase, 2003). Later, the Seventh Five Year Plan (1985-90) played a pivotal role in bolstering the use of EIA in other sectors, such as agriculture, industry, tourism, water resources, transportation, urbanization, and forestry (NCSIP, 1994; UNESCAP, 2003). Efforts to put EIA into practice were further strengthened with the authorization of the National Conservation Strategy by the Government of Nepal and the implementation of an EIA to understand the impacts associated with tasks in the Master Plan for Forestry Sector in 1987. Similarly, the interim Government of Nepal in 1990-91 supported use of EIA for any undertakings that would leave unwanted impacts in the environment. The Eighth Five Year Plan (1992-97) formally endorsed incorporation of EIA in economic activity, use of

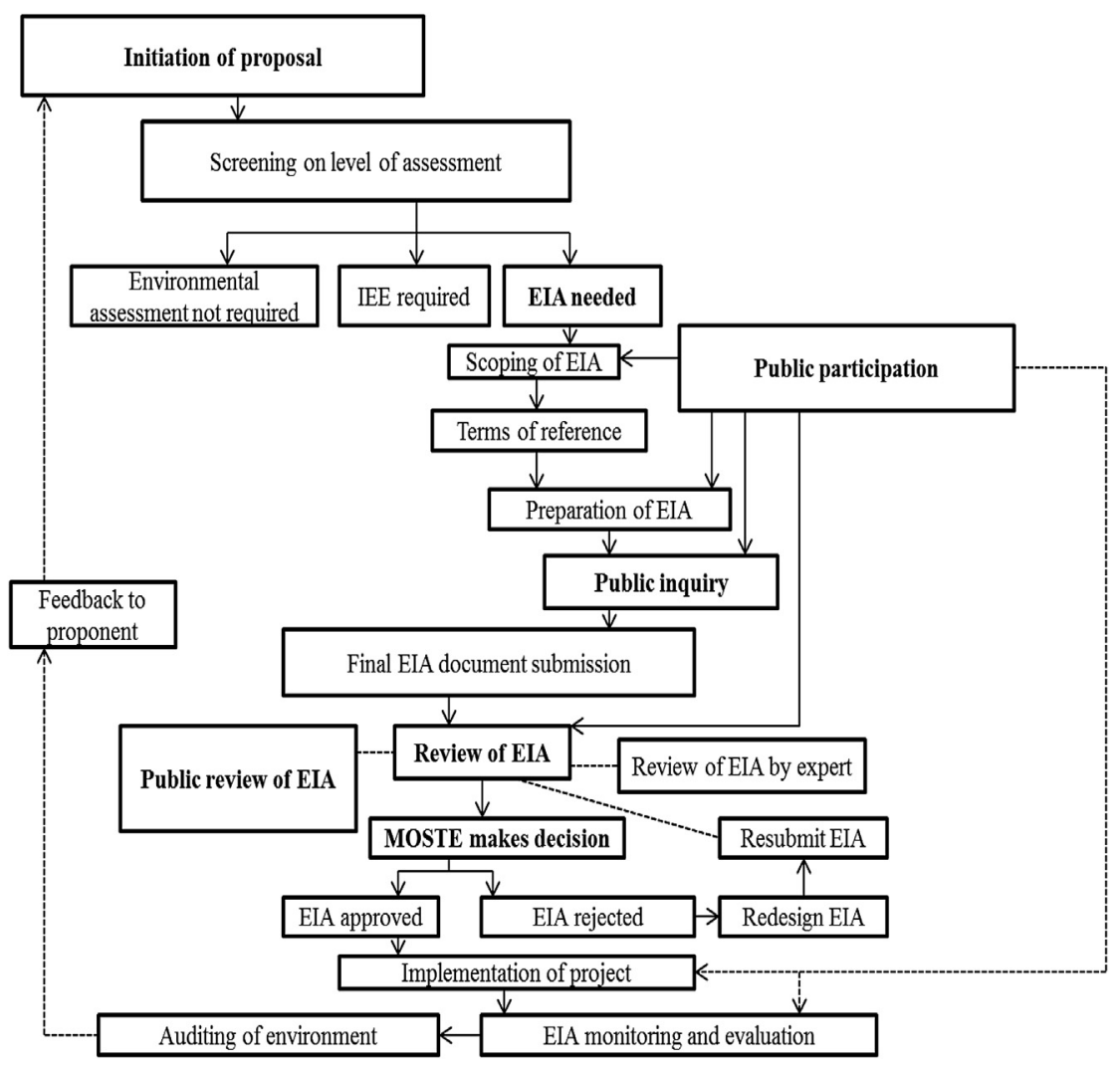

Fig. 1. Schematics of EIA process in Nepal adapted from Uprety (2003). IEE = Initial environmental examination. 


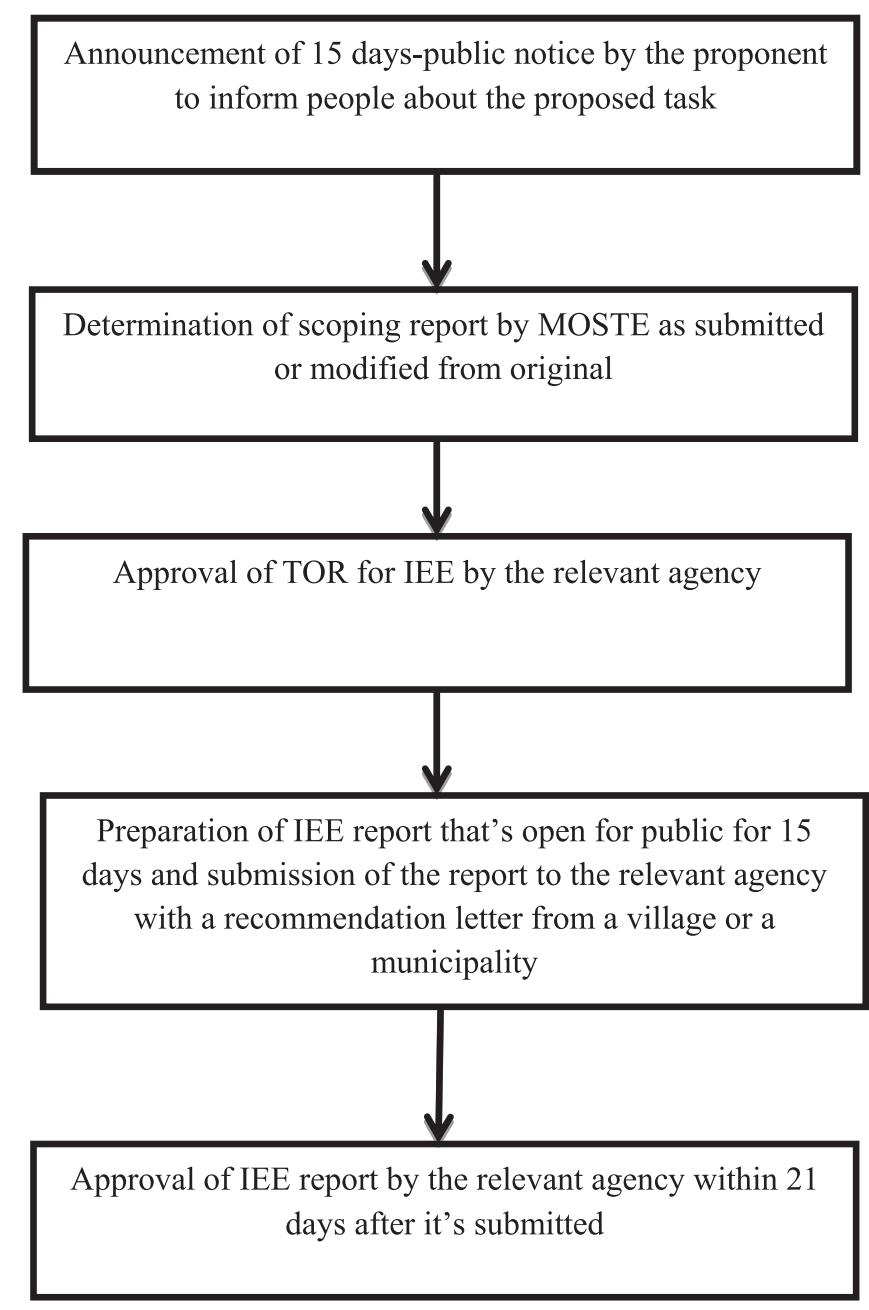

Fig. 2. IEE process in Nepal (Anneveldt \& Pasman, 2001). TOR = Terms of reference.

integrated concepts, sustainability approach, creating an environmental unit in a government ministry, developing standards and indicators, and initiation of developmental tasks only after EIA studies (UNESCAP, 2003). In this period, the Government of Nepal institutionalized EIA through the National Environmental Impact Assessment Guidelines 1993. Following this daring move toward environmental conservation and sustainability, Nepal established the Ministry of Population and Environment (MOPE) on December 13, 1995. ${ }^{1}$ Consequently, Nepal enacted milestone environmental legislation in Nepal's history, viz. the Environment Protection Act 1996 and Environment Protection Rules 1997 (EPR). Together, these laws are known as the Environment Protection Act (EPA).

Before 1993, donor-funded projects followed EIA, and some public projects particularly in industry, forestry, and hydropower required both initial environmental examination (IEE) and EIA. Following the promulgation of EPA, private developers are also required to carry out IEE and EIA studies. The details of IEE and EIA policies for SWM projects are included in schedules 1 and 2 of the EPR 1997, respectively (Anneveldt \& Pasman, 2001). The goal of IEE is to discern whether a project necessitates EIA if it's unclear from initial screening. A flowchart showing the typical steps concerning EIA in Nepal is included in Fig. 1. Fig. 2 shows the steps for IEE. IEE

\footnotetext{
1 MOPE is now part of Ministry of Science, Technology and Environment (MOSTE).
}

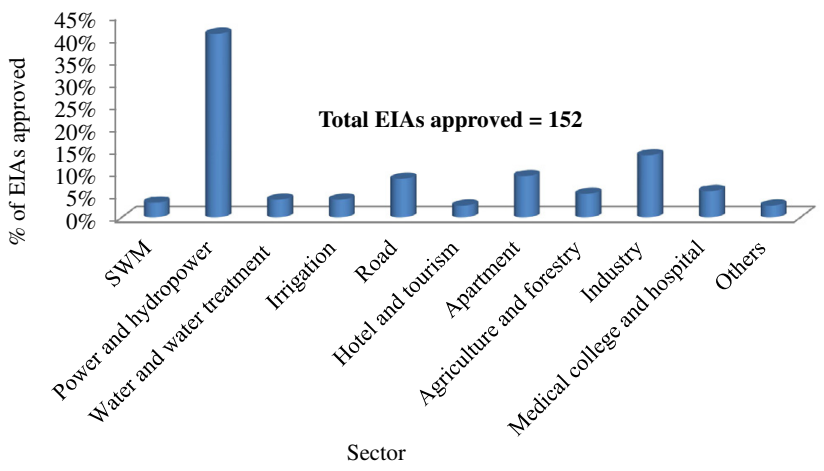

Fig. 3. Percentage of EIAs issued in Nepal (MOSTE, 2013).

reports may be further examined by the MOSTE Review Committee if deemed necessary. Usually MOSTE is the responsible authority for approving EIA, whereas the relevant agency or line ministry is in charge of making decisions regarding IEE.

\section{Sectoral development of EIA in Nepal}

By 2003, twelve EIA reports concerning industry, roads, hydroelectricity, and pesticides were permitted and 30 projects for which scoping and terms of references were approved within three years had gone through the EIA process since EPR came into effect (UNESCAP, 2003). About 50\% of the approved projects were in the water resources sector. The number of approved EIA stood at 72 by October 2007 with 12 for forestry and agriculture, 11 for drinking water and roads, 5 for hospitals, 3 for hotels and tourism, 29 for water resources, and 12 for industry and waste management (Uprety, 2007). The EIA section at Ministry of Environment (MOE) ${ }^{2}$ reported on July 20, 2011 that MOE had approved 120 EIAs, including 30 for the hydropower sector and only four for SWM projects. Bhatt and Khanal (2010) presented the following detailed breakdown of 100 EIAs issued across sectors: $25 \%$ hydropower, $14 \%$ transmission lines, $10 \%$ road, $9 \%$ industry, $5 \%$ waste management, $4 \%$ drinking water, $11 \%$ agriculture and forest, 3\% each hotel and tourism development, irrigation and apartment buildings, and $12 \%$ others. A recent publication from MOSTE (2013) indicates that 152 EIAs have been approved (Fig. 3). Among the EIAs issued, 3\% of them belong to SWM, $41 \%$ for power and hydropower, $4 \%$ each for water and water treatment and irrigation, 9\% road, 3\% hotel and tourism, $9 \%$ apartments, 5\% agriculture and forestry, $14 \%$ industry, $6 \%$ medical colleges and hospitals, and 3\% others. Results largely show a low number of EIAs conducted in SWM whereas power and hydropower, apartments, industry, roads, and medical colleges and hospitals have witnessed gains in recent years.

The absolute number of EIAs issued in power and hydropower stands out at 62 in comparison to 39 for combined hydropower and transmission lines identified by Bhatt and Khanal (2010). Also, the number of EIAs in hydropower alone at 30 mentioned by MOE in 2011 correlates with 25 reported in 2010 by Bhatt and Khanal (2010). However, EIAs for SWM stood at 5 in a study by Bhatt and Khanal (2010) and 4 according to MOE in 2011, and again at 5 in the most recent publication by MOSTE (2013). One inconsistency in accounting for these EIAs may be attributed to the definition of sectors and ways by which EIAs were allocated to each of the sectors.

\footnotetext{
2 MOE became a part of MOSTE on May 18, 2012.
} 


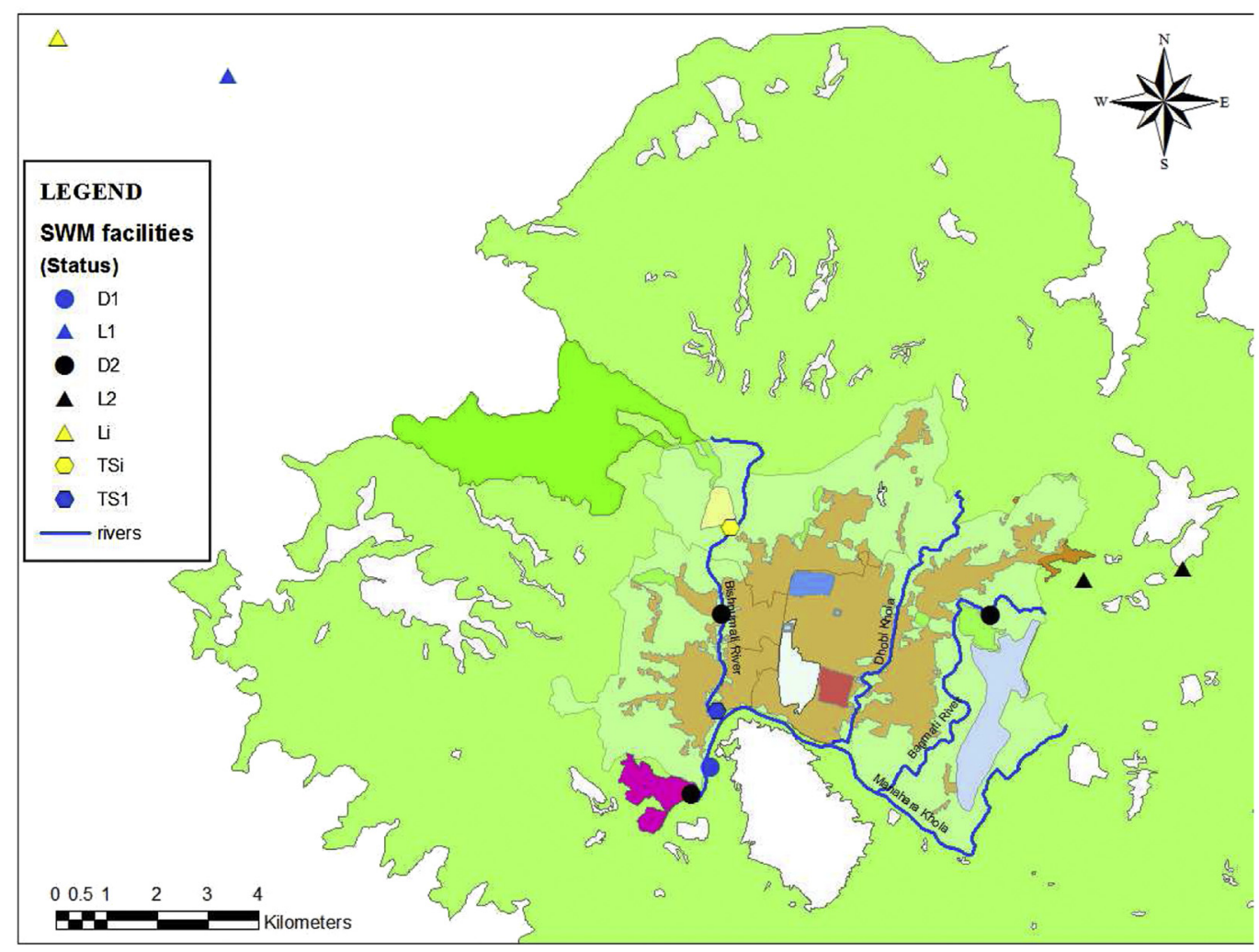

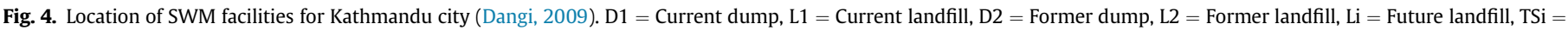
Future transfer station, TS1 = Current transfer station.

Sectoral development of EIA in Nepal advanced in the 1990s with two distinct EIA guidelines for the industry and forestry sectors in 1995. The Hydropower Development Policy 1992 and the Irrigation Policy 1993 (revision 1997) also emphasized the need for IEE and EIA (UNESCAP, 2003). For SWM, the Ninth Five Year Plan 1997-2002 recognized recycling, involvement of the private sector and non-governmental organizations in SWM, and use of compost; and the Tenth Five Year Plan 2002-07 mentioned monitoring of suitable SWM indicators and construction of a long-term landfill for Kathmandu Valley municipalities in Okharpauwa, Nuwakot district (Dangi, 2009). But, the National Environmental Impact Assessment (NEIA) Guidelines for Solid Waste Management Projects for Municipalities of Nepal weren't finalized until 2005 (ERMC (P.) Ltd., CCON (P.) Ltd., \& Masina Continental Associates (P.) Ltd., 2005). More on NEIA guidelines can be found in Dangi (2009) and ERMC et al. (2005).

\section{Methods}

Because EIA policy is comparatively recently established law in Nepal, particularly in SWM, the research shortlisted and studied a number of active, closed, and proposed landfill locations for Kathmandu city, the capital of Nepal. (See Fig. 4.) Kathmandu Valley has five municipalities, viz. Kathmandu, Lalitpur, Bhaktapur, Kirtpur, and Madhyapur Thimi, along with several villages. Sisdol and Aletar are two landfills adjacently located near the northern bank of Kolpu Khola (river), $28 \mathrm{~km}$ northwest of Kathmandu city in Okharpauwa, a village in the Nuwakot district. Two km west of there is a proposed location for Banchare Danda (hill) Landfill Site (BLS), a future landfill for Kathmandu Valley municipalities. Gokarna landfill is a closed site situated $16 \mathrm{~km}$ northeast of Kathmandu city. Tathali, Pharsidole, and Sangletar are three other proposed landfill locations for Kathmandu Valley municipalities.
Since the methods of combining qualitative investigations with quantitative information have been previously tested by Dangi, Urynowicz, Gerow, and Thapa (2008), Dangi, Pretz, Urynowicz, Gerow, and Reddy (2011), and Dangi, Urynowicz, and Belbase (2013), this research conducted a similar field study in June-July 2010 to examine the actual application of EIA policy in SWM projects in Kathmandu Valley and different tasks associated with the field study are presented below.

\section{Survey}

An interview survey was conducted among 64 households in Okharpauwa and Chhatre Deurali villages using cluster sampling techniques followed by systematic sampling. To minimize the cost of sampling in mountainous terrain and accounting for the low number and scattered distribution of households around landfill locations, a sample size of 64 was chosen for this study. First, the active landfill, Aletar, was treated as the focal point and four directions (east, south, west, and north) were identified using global positioning system. Then, four villages were recognized as immediately adjacent to Aletar landfill in the four directions: Soti in the east, Panchmure tole in the south, Dhande in the west, and Challetar in the north. ${ }^{3}$ With the help of local residents, all villages surrounding Aletar were ranked and it was confirmed that the four adjoining communities chosen were the most affected by the landfilling activity. Given the ruggedness and topography of the hilly districts of Nuwakot (Okharpauwa) and Dhading (Chhatre Deurali), the settlement patterns and trails did not follow linearity. ${ }^{4}$ The physical layouts of the locality presented challenges in

\footnotetext{
3 Tole is a Nepalese word for a cluster of households belonging to a certain neighborhood in a village or a city.

${ }^{4}$ In this study Okharpauwa is used to denote these two vicinities.
} 
Table 1

List of individuals interviewed.

\begin{tabular}{|c|c|c|}
\hline $\begin{array}{l}\text { Names/ } \\
\text { individuals }\end{array}$ & Affiliation/information & $\begin{array}{l}\text { Date of } \\
\text { interview }\end{array}$ \\
\hline A local resident & An elementary school Principal & June 29, 2010 \\
\hline A local resident & A landless resident & June 29, 2010 \\
\hline Annonymous & $\begin{array}{l}\text { Engineer, one of the Kathmandu Valley } \\
\text { municipalities }\end{array}$ & July 20,2010 \\
\hline Meera Joshi & Undersecretary, Ministry of Environment & July 7, 2010 \\
\hline $\begin{array}{l}\text { Dr. Ram B. } \\
\text { Khadka }\end{array}$ & EIA Expert and Consultant & July 9, 2010 \\
\hline $\begin{array}{l}\text { Ram Saran } \\
\quad \text { Maharjan }\end{array}$ & Engineer, Ministry of Local Development & July 8, 2010 \\
\hline $\begin{array}{l}\text { Bhai Raja } \\
\text { Manandhar }\end{array}$ & $\begin{array}{l}\text { In Charge of EIA Evaluation, Ministry of } \\
\text { Environment }\end{array}$ & July 7, 2010 \\
\hline $\begin{array}{l}\text { Rajesh } \\
\text { Manandhar }\end{array}$ & Sanitation Officer, UN Habitat & July 21,2010 \\
\hline $\begin{array}{l}\text { Dipendra } \\
\text { Bahadur Oli }\end{array}$ & Legal Officer, Ministry of Local Development & July 8, 2010 \\
\hline Vinod Sharma & Director, Advance Energy System & July 9, 2010 \\
\hline Street sweeper & Kathmandu Metropolitan City & June 29,2010 \\
\hline
\end{tabular}

coming up with equal numbers of households per village in each direction. In some cases the boundaries of the villages were too narrow with very few households. Therefore, 15 households each were selected from the north, east, and south directions and 19 households were allotted from the west. Four student scientists who had completed human subjects research education performed interview surveys using 30 structured questionnaires printed in the Nepali language on July $2-3,2010$. The survey questions are provided in Appendix. ${ }^{5}$ The questions were targeted to examine the demographic and socioeconomic background of respondents, learn more about implementation of developmental accords reached between the government and villagers, determine whether or not public hearings were conducted while drafting the EIA report, examine the level of environmental compliance in the area, and assess the overall effort of the proponent in employing the EIA instrument in the landfill project. The survey questions were analyzed using statistical package for social scientists (SPSS) version 22.0

\section{Interviews}

Eleven separate interviews were conducted from June 29 to July 21, 2010 with people from different levels of authority, expertise, involvement in EIA processes, and walks of life (Table 1). A U.S. student conducted all of the interviews and recorded them using an iPod classic 30 GB Model MA002LL Version 1.3. A Nepalese student also typed up the interview responses as a backup. The recorded interviews were later examined and compared with the handtyped transcripts. The information derived from interviews was utilized to triangulate data from other sources. Open-ended discussions about the EIA with people from varying backgrounds and understanding proffered the opportunity to extract the level of public confidence sought by proponents in solid waste projects as well as determine the actual steps taken by authorities to practice the EIA instrument.

\footnotetext{
5 The actual survey questionnaires included a table at the beginning of the survey instrument that contained researcher's information, household code, type and distance from landfill, names of the village/tole and district, interviewer's name, respondent's gender, and time and date of the survey. This was followed by short consent form. In addition to 30 structured questions, an additional open-ended question was enlisted at the end of the survey to seek any extra information not covered by the questionnaire.
}

\section{Field observation}

Researchers visited Gokarna landfill and a proposed landfill location in Tathali on July 4, 2010 and two other proposed sites in Sangletar and Pharsidole on July 5, 2010. The visits scrutinized the application of EPA in solid waste projects and assessed how the safety of people living near landfill locations is ensured. Because the multiple proposed and past landfill project locations were developed in different time periods, the site visits provided data on whether contemporary government policies were applied or not and a comparison of the efficacy of different methods. Also, first author and his students visited Sisdol landfill and consulted with Kathmandu city engineers to learn the current condition of that facility on May 21, 2013.

\section{Focus group interviews}

Except in the Aletar area, focus group interviews were conducted in the landfill or proposed landfill locations. Student scientists assisted by Nepalese students dispersed in teams of two from the main solid waste facility in each location to each of the four directions and interviewed more than two residents at a time. In all of the focus group interviews, a student scientist asked questions and facilitated the dialogue with villagers and another student scientist typed the response. Later, they both went over the data to minimize any inconsistency in reporting before handing it to the lead researcher. The lead researcher (first author) then compiled and analyzed the information. This method was useful to cross-check information gathered by each team of students from the focus group interviews. The local residents' firsthand descriptions of facilities before and after project completion provided invaluable information about sites, public expectations, governmental commitment, and any outstanding issues related to the projects.

\section{Theoretical approach and EIA report preparation}

Researchers have utilized various attributes to understand the effectiveness of EIA tools. Ortolano, Jenkins, and Abracosa (1987) used control mechanisms, which include practices, processes, and structures used for environmental compliance within and between organizations. Leu, Williams, and Bark (1997) described nine different quality control parameters to comparatively study EIA systems in Indonesia, Malaysia, and Taiwan. Ahmad and Wood (2002) mentioned three attributes in evaluating EIA in Egypt, Turkey, and Tunisia: governmental framework for EIA, steps of EIA, and actions implemented to boost EIA. Similar benchmarks were adopted in judging EIA processes in Bangladesh (Momtaz, 2002), China (Li, Ng, \& Skitmore, 2012), India (Panigrahi \& Amirapu, 2012), Sri Lanka (Zubair, 2001), and Trinidad and Tobago (Brown \& Jacobs, 1996). Wood (2003) outlined 14 EIA assessment criteria grounded on the illustration of phases in the EIA methods, objectives of EIA and different evaluation features to investigate similarities and differences among EIA systems of seven developed and developing countries. Bartlett and Baber (1989) stated that the feelings and views of individuals involved in crafting EIA carry more weight in the appraisal of EIA. Similarly, culture and local economy play a quintessential role in the application of an EIA process (Panigrahi \& Amirapu, 2012). Realizing the dominance of Nepali politics in everyday life and the distinct role individuals with authority play in decision making, this study extensively employed consultation with people from various walks of life involved in the process to survey the legal framework described in Evolution of EIA in Nepal section above and evaluate EIA report preparation and public participation (Table 2). 
Table 2

Attributes identified to understand EIA of SWM projects in Nepal.

\begin{tabular}{|c|c|}
\hline Attributes & Questions \\
\hline Legal framework ${ }^{\mathrm{a}}$ & $\begin{array}{l}\text { What major policy instruments are available to } \\
\text { regulate environmental assessments in Nepal? } \\
\text { How have they been utilized in different sectors? } \\
\text { Are there any policy tools to support EIA in SWM } \\
\text { projects and have they been effective? }\end{array}$ \\
\hline $\begin{array}{l}\text { EIA report preparation } \\
\text { and participation }\end{array}$ & $\begin{array}{l}\text { What relationship does public participation have } \\
\text { with public inquiry, review of EIA, and project } \\
\text { implementation? } \\
\text { How are public comments and concerns included } \\
\text { and addressed in EIA reports? } \\
\text { What role do affected parties have in the preparation } \\
\text { of EIA documents? }\end{array}$ \\
\hline
\end{tabular}

a Wood (2003).

Also, because so few EIAs have been completed for the SWM sector in Nepal, researchers scrutinized its procedures and usefulness by examining the details of its practice. Anecdotal evidence shows that EIA reports are not created according to accepted standards, and government authorities fail to involve the public in the EIA process. In general, the public is dissatisfied with the EIA process. For example, in Okharpauwa, among the 64 households that participated in the survey, $91 \%$ of them were unsatisfied with the actions of government services and $69 \%$ of them were unaware of any alternate landfill locations during the development of a longterm disposal facility. Similarly, only $14 \%$ of the respondents were happy with the public participation conducted whereas $59 \%$ of them were unhappy or very unhappy with the results of the entire EIA process.

Similar deficiencies in theory and practice of EIA were reported by Lo, Yip, and Cheung (2000), Obbard, Lai, and Briffett (2002), and Tan (2004) in analyzing environmental tools in China, Vietnam, and in Southeast Asia, respectively. In Vietnam, there seem to be clear deficiencies in the ability and experience of experts in preparing scoping documents, measuring impacts of the proposals, devising and implementing public meetings, and overall enhancement of environmental auditing procedure (Clausen, Vu, \& Pedrono, 2011). Also, Appiah-Opoku and Bryan (2013) mentioned that environmental documents in Ghana lack technical facts, understate actual impacts associated with projects, limit information on alternate sites for proposed activities or negative effects, and largely fail to capture local involvement. Citing shortages of experts and monetary resources, Nadeem and Hameed (2010) emphasized the need for skill development for efficient application of EIA and follow-up practices in Pakistan and other developing countries. Likewise, Morgan (2012) also identified weaknesses in institutions, proponents, level of training, and capacity building as problems in impact assessment.

While Belbase (2003) and Uprety (2007) related that sectoral guidelines of EIA began in forestry and industry in 1995, Belbase (2003) mentioned that EIA guidelines for SWM project have been also developed. These guidelines are very poorly written and do not appear to be supported by scientific research because no citations are included. For example, the statement, "In addition, badly managed landfilling produces leachate (liquid waste), which can contaminate surface and ground water sources" (ERMC et al., 2005:1), displays a weak understanding of solid waste processes by the preparers because all landfills generate leachate as a function of heat, pressure, and temperature in landfill cells, but at different rates. By stating that the main objective of the guidelines was to enhance municipal environments via appropriate management of solid waste, they fail to capture importance of the biophysical, social, and environmental impacts at project sites away from city areas.
Upon revisiting existing EIA documents for SWM projects in Nepal, the study unearthed that the reports were very poorly written with repeated grammatical and syntax errors, redundancy and overlap of information between sections, missing information, texts and captions copied from other reports, and lack of details on standard techniques used during surveys and collection of primary data. Anneveldt and Pasman (2001) emphasized that these EIA reports are too technical, generally printed in the English language, and lack multidisciplinary teams of experts, as well as reported that IEEs never lead to EIAs because proponents hide any significant impacts that IEEs may find. They added that public hearings are never conducted during EIA report preparation. Any hearings that may be conducted are held after the completion of the reports to seek letters of support from village officials, which bars affected parties from contributing in an EIA study.

The EIA of BLS prepared by GEOCE Consultants (2009) fails to list alternative landfill locations for the project. Instead of discussing alternative locations, the report simply describes the design alternatives of BLS by covering how semi-aerobic landfills work, waste storage dams, leachate treatment options, gas collection methods, and a drop channel for river diversion. Unlike in typical environmental documents where alternate proposals are evaluated and short and long-term irreversible and irretrievable impacts are compared against the potential project work and benefits, the authors of this EIA state that BLS was the only available site for the disposal of solid waste from Kathmandu Valley municipalities (GEOCE Consultants, 2009).

According to UNESCAP (2003), the EIA tools in Nepal lack accreditation and usually disregard the consequences of large-scale policies, including evaluation of cumulative impacts. Also, there is a lack in skilled personnel and the process is burdensome and approval takes a long time. Proponents perceive that the environment is sufficiently managed upon approval of EIA. The report additionally summarizes that EIA procedures are paralyzed by the inability to create databanks and circulate knowledge, fall short in applying suggestions of EIA into final design and agreements, espouse impromptu measures in analyzing proposals, and fail to provide monitoring and evaluation. Similar findings about EIA practices in Nepal were reported by Belbase (2003), where he narrated that the public is not consulted during the early phase of project planning, EIA reports are written in the English language which local people cannot understand, MOSTE is incapable of auditing projects, and proponents use EIA as a retroactive tool to mitigate problems and employ it very late in the development phase. There is a general belief that approved EIAs can themselves manage the environment, it takes long time to review EIAs and there are no reviewing guidelines, there is a dearth of organizational apparatus and trained personnel, and developers are unhappy with deferrals in approval of EIAs and are compelled to corruption (Belbase, 2003). Furthermore, emphasizing unethical activity among EIA consultants, Belbase (2003:10) states, "A tendency of cutting and pasting from previous EIA reports and presenting uncalled for data to make the reports voluminous is on the rise." Even though the EIA consultants are required to have at minimum a Bachelor's degree in environmental science, engineering, forestry, botany, or biology, they are not accredited (Joshi, 2010). Joshi (2010) recounts that the EIA for BLS took a year and a half to get approval and the time for approval depends upon the quality of the report. Sometimes people copy even non-relevant information from other reports, including consultants extracting information from other reports and counting it as their own.

Problems with EIA processes are linked to substandard EIA reports prepared by consultants, the inability of proponents to comprehend the information included in the reports, unaccredited report preparers, lack of public hearings where the projects are 
proposed, omitting reports of public hearings from the documents, copying and using fragmented pieces from other EIA reports, and submission of EIA after the construction of projects (Uprety, 2007). ERMC et al. (2005) highlighted the need to complete EIA before undertaking any SWM projects since 1997 and compulsory requirement of public participation through the endorsement of the projects by village, city, and district committee offices, schools, or other organizations; however, very little of this practice was adopted in Okharpauwa. Also, the construction of Sisdol landfill site before the completion of EIA documented by Nippon Koei Co. Ltd. and Yachiyo Engineering Co. Ltd. (2004) and Dangi (2009) further corroborate the violation of EPA rules in SWM projects.

\section{Public participation in EIA of SWM projects}

The Nepalese EIA system requires three public consultation periods, one each during the scoping, field study, and approval phases. In spite of these required hearings and the public hearing held while preparing the draft EIA, the EIA for BLS contains little public comment or input, undermining national law and local stakeholders. In a survey question, $66 \%$ of the respondents stated that they didn't attend or know about any public meeting called for BLS or other temporary landfill sites whereas $13 \%$ expressed that the program began with a description of proposal and anticipated effects, and $17 \%$ mentioned that multiple ways were employed to inform public (Fig. 5). NEIA guidelines outline twelve different methods that can be employed in educating local citizens (ERMC et al., 2005) and yet only 6\% of respondents received their information from public notices and $9 \%$ from radio and television. With very high number of households surveyed (66\%) reporting that they lacked public information and only small number of them receiving it from recommended sources, the EIA procedure does not seem to be concerned with public involvement.

While the number of people aware of BLS has increased from $9 \%$ in 1993 to $55 \%$ in 2003 and $97 \%$ in 2010 (Table 3), the proposed landfill is far from being built. During the May 2013 visit, it was uncovered that Sisdol landfill had reopened after being closed from November 2009-July 2011 and solid waste was being deposited on top of the old refuse cells. The inability to build a permanent landfill, i.e. BLS, twenty years after the need for it was identified further shows the government's lackluster performance in fulfilling local commitments. More on governmental promises can be found in Dangi (2009). Additionally, linking this area with Kathmandu via an access road has attracted more recent development and construction of newer homes. While uncontrolled disposal of solid waste in Sisdol, depositing medical and industrial wastes in it,

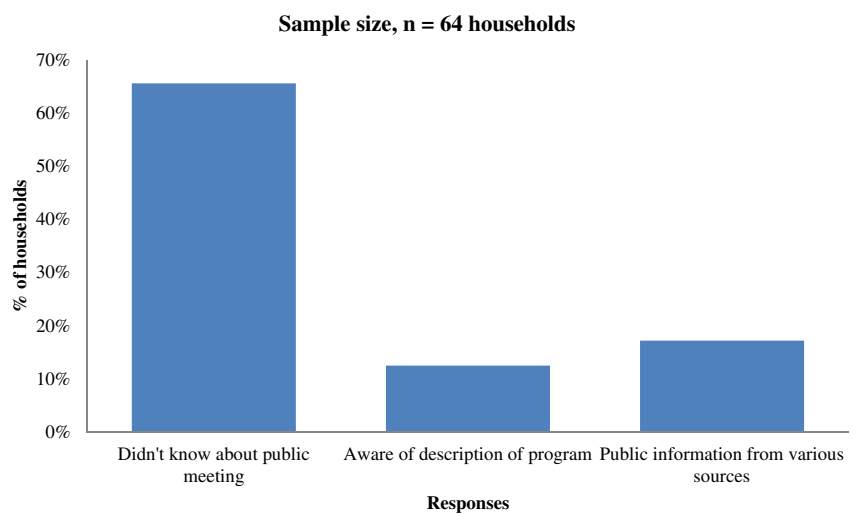

Fig. 5. Households' responses to knowledge of public meeting conducted before the construction of landfills.
Table 3

Percent of people aware of future landfill (BLS) in Okharpauwa.

\begin{tabular}{lc}
\hline Year & Percentage \\
\hline 1993 & 9 \\
1994 & 14 \\
1995 & 22 \\
1996 & 23 \\
1997 & 25 \\
1998 & 36 \\
1999 & 38 \\
2000 & 41 \\
2002 & 47 \\
2003 & 55 \\
2004 & 59 \\
2005 & 69 \\
2006 & 77 \\
2007 & 81 \\
2008 & 83 \\
2010 & 97 \\
\hline
\end{tabular}

applying no soil cover to wastes, and rampant discharge of leachate into Kolpu Khola have deteriorated the environment; the prolonged delay in landfill construction could be further complicated via increased urbanization. In our query to learn measures taken to stop disposal of solid waste and discharge of leachate into rivers, Khadka (2010) responded, "There are so many plans and studies but no funds for action ... This is common in Nepal. We get a lot of funding for studies but not for any action. Nothing gets done; it's all about how you fool the people. Everybody comes here with big amounts of money and part of the money goes to study and the other goes back to their country or donor. It does not actually go to implementing the project."

A senior division engineer at the Environmental Assessment section of MOE commented on the direct release of leachate from Sisdol to Kolpu Khola, "It is a large concern for us as well, we are aware of it and it is the weak link in the EIA process. The reason behind this is basically the ministries are understaffed and technically understaffed ... whether we like it or not it is the fact ... in this ministry, in just one month back, there were only two of us working in this department taking care of all the EIA proposals for the entire country. So you can understand why we have no time to make site visits" (Manandhar, 2010a). He agrees that building a state-of-the-art facility without maintaining or monitoring it is a waste of energy and resources and adds that they don't have the manpower to monitor Sisdol. He states that the government overlooked the details while developing EPA and failed to empower the Ministry to carry out the spirit of the law. He questioned how, with only two people, the Ministry could be productive or the two people can do their jobs. He expressed that the law was a good step when it was first developed, and people were excited and expected the Ministry to grow, but instead it has decreased in size (Manandhar, 2010a).

There are no procedures or technical personnel to monitor leachate in Sisdol. And, even though the equipment is there, the electricity supply is unreliable at best. The power goes out so frequently that it is difficult to sustain a working system and the aerators are damaged (Maharjan, 2010). The government has money and a plan, but leachate is collected in ponds and allowed directly into Kolpu Khola because there are no means to implement any measures. People are complaining about health issues, and they cannot walk down into the river because of its smell and toxicity. A government engineer asked, "Who will fix aerators? What organization? I'll tell you what happened, the equipment was there but the residents stole the pipelines and wires. Now nothing is there. The same people that are complaining are the people who are 
stealing" (Maharjan, 2010). Within the last four years of operation, the Sisdol and Aletar landfills have been closed for a total of 288 days because of strikes by local people (Maharjan, 2010). Because there is no instrument for enforcement, no one can take any action on these things (Maharjan, 2010). Similarly, the Sisdol landfill was supposed to have a buffer zone, according to the EIA. It was learned that the government was trying to acquire land for it after the approval of EIA (Oli, 2010). Within an EIA there are so many things promised, such as the treatment of leachate and buffer zones, but nothing is being done. People are complaining in landfill locations while people seem to be happy with other developmental activities. The EIA for landfill projects is not fully realized (Maharjan, 2010). Citing the landfill management practice at Sisdol, Maharjan (2010) claimed that it is a complete failure.

Generally, the EIA for SWM projects in Nepal is carried out after sites have been selected. Technical or geographical limitations are not considered; instead it is a political decision. For example, a political leader, the Mayor of Kathmandu, decided that the Okharpauwa was feasible for a landfill site (Anonymous, 2010; Dangi, 2009). If the permanent landfill is not built in Okharpauwa, there is a chance that municipalities may revert to riverbank disposal of solid waste in Bagmati River, which can pose hazards to human health and the environment. Realizing the seriousness of this problem, an engineer at one of the Kathmandu Valley municipalities requesting anonymity stated, "We know ... our Supreme Court has already ordered us to stop dumping [into rivers]. The court also threatened a stiff penalty, and every four months we have to send a progress report. If it is false, then they charge for punishment. Every month I go to the Supreme Court ... to defend [the municipality] ..." (Anonymous, 2010). Lack of personnel at MOE is another problem. There is only one person looking after EIA and the individual is never available in Nepal. Clauses that require public hearings followed by documentation and waiting periods of 90 days for approval of EIA are some of the difficulties. EIA would be feasible to evaluate two or three candidate sites; in the case of Okharpauwa, this site already belongs to the government; so, they believe they already know the answer and feel that there is no need for EIA (Anonymous, 2010). The anonymous engineer (2010) deems that with EIA there should be $100 \%$ of support from local people to build a landfill in BLS unlike a $90 \%$ agreement to allow waste disposal as long as the government fulfills their local developmental needs while $10 \%$ are still opposed. He further adds, "So what we are doing is we are selecting only some political representatives from the area and we sit in a room and we are saying the public hearing is done. That's what we are doing. That is the process actually ... in Sisdol also the same (thing) happened. One day before the approval of the EIA, all the stakeholders were at a meeting and only $5 \%$ of the local community" (Anonymous, 2010).

The final EIA report of BLS states that a public hearing was conducted on February 3, 2008 in Kudule, Chhatre Deurali that was attended by 210 people. Among the proponents, representatives from Kathmandu and Lalitpur municipalities did not attend the meeting and neither did the consultants who prepared the report. It was unclear if all of the 48 written comments received from the public hearing were addressed by the government. Also, names and signatures of attendees were missing from the report. Many annexes of the report have blank pages or tables without any biological, physical, and socio-economic measurements. The caption on these tables reads, "EIA Study of Clean Kathmandu Valley ...", a different project (GEOCE Consultants, 2009). Also, having conducted a public hearing after the completion of the report that was attended by the government officials points to the promotion of a backdoor policy by the responsible authorities to avoid public participation and a ploy to receive endorsement letters from village officials. The EIA report lacks support letters from district committee offices, schools, or other organizations. Earlier, Dangi (2009) also reported that annoyed villagers blocked attempts to accomplish environmental studies by consultants in Okharpauwa, which suggests that a true public consultation never took place for BLS.

To find out whether local residents in Okharpauwa area were capable of understanding public notices, a survey question designed to seek their level of education revealed that a large majority of them (69\%) were not educated and barely $5 \%$ had some high school education (Fig. 6). This was supported by the fact that $77 \%$ of the respondents were engaged in agriculture, $8 \%$ in business, and merely $2 \%$ in public service (Fig. 7 ). Although notices published in newspapers are posted locally, it is expected that literate people will spread this information to illiterate ones. The irony is if any public comments are included in the EIA report, they receive no response (Khadka, 2010). None of the 48 written comments received during the public hearing were included in the final EIA of BLS nor does the report include any references used (GEOCE Consultants, 2009). Also, the fact that most of the people are not educated makes the newspaper an ineffective tool to communicate; therefore, the government needs to use multiple methods that are suitable with the public's level of education and local customs and culture to inform the public about new projects and proposals and respond to their comments.

BLS is environmentally and financially infeasible for a landfill (Manandhar, 2010b). While municipalities in Kathmandu Valley bear the high transportation cost associated with hauling of waste to Okharpauwa, they are unable to work with the Ministry of Local Development (MLD) in finding alternate locations as illustrated by this response to the former solid waste chief of Kathmandu city, "Okay, find us a landfill site that is suitable to you, then we will build a landfill site there" (Manandhar, 2010b). Manandhar (2010b) added that there is no place else to deposit waste, so this is another facet of the issue. In discussing how exactly new landfill sites are identified, Manandhar (2010b) shared his experience with Kathmandu: first a consultant came and studied the potential locations using a geological survey; they identified ten sites; he visited nine or ten sites with the consultant in 1998-99; and the decision was based on the soil samples. But when he analyzed the downsides of the sites including financial burdens, transportation issues, proximity to the airport, insufficient land, and too near to the river; he kept his mouth shut because if he wanted to say no to BLS, he had to have an alternative site identified (Manandhar, 2010b).

To determine whether the government performed its due diligence in securing a new landfill, focus group interviews were

Respondents level of education, $n=64$

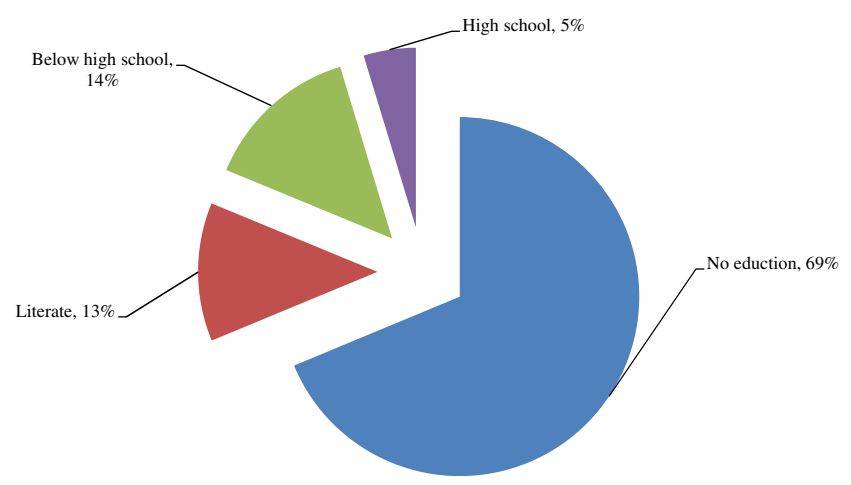

Fig. 6. Respondents' level of education. 


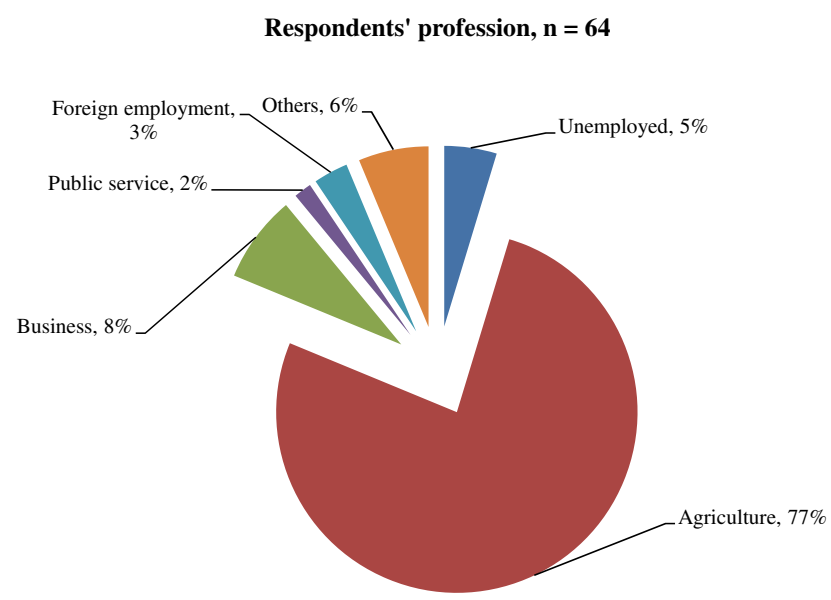

Fig. 7. Respondents' profession.

conducted at three proposed landfill sites. The visit to Tathali uncovered that villagers rejected the attempt to build a landfill there around 2005 because of strong opposition. Neither EIA nor public hearings were conducted in this area. It appeared that Bhaktapur Municipality wanted to build a landfill there and when the local people objected the government and politicians threatened to annex the village into Bhaktapur Municipality. The villagers then filed a case against that potential move in court and protested to prevent the construction of the landfill.

A visit to Pharsidole unveiled that the government proposed to build a landfill in this location in 1998, which led local people to draft a series of demands the government would have to meet to garner their support. However, the plan was later canceled citing its geography aligned along the flight pathways. For Sangletar, $100-200$ people were selected to attend a public hearing in 2000, while a majority of the residents in the area still opposed it. Kathmandu city preferred this site because it is close to the city. Nonetheless, the proposal later was dropped noting its small size and the government instead chose Okharpauwa.

The focus group interview report from Gokarna yielded that since the closure of the landfill in 2000 no post-closure maintenance has been done. Now, local citizens complain about health effects (though few were employed by the landfill) and contaminated ground water. Even after the shutdown the landfill was still receiving waste. Currently the Nepal Army and cricketers have occupied the area because government has ignored the postclosure activity saying that the landfill was constructed prior to the enactment of EPA and they lack a legal framework to conduct the work.

\section{Conclusions and recommendations}

This study examined the theory and practice of EIA in Nepal's solid waste sector and found that Nepal's EIA is still at its initial stages primarily because the legal structure of EPA and NEIA is still maturing and lacks key components, including the use of environmental inspectors, technical capacity, institutional strengthening, EIA accrediting procedures, monitoring of project activity, and educating people at project sites and gaining their support. The current structure is weakened by the exceptionally high level of public dissatisfaction, inability to conduct public hearings at the sites, autarchic selection of landfill locations by the government, failure to determine alternate locations, conducting public hearings with political representatives, and using inappropriate public notice methods. Any attempts to identify a new landfill for
Kathmandu have been stymied by the government's track record of reneging on local accords and failing to restore closed landfill projects.

Nepal has an opportunity to shore up the legal framework for environmental regulations. The NEIA requires major revision to reflect local technical conditions and limitations to succeed in SWM. Proponents of EIA should be required to thoroughly alert the populace and consult stakeholders from the preliminary phases using creative ways of carrying out public hearings and apprising individuals that account for high illiteracy rates. In addition, strengthening human capacity at MOSTE; streamlining approval procedures of EIA; training EIA preparers; forming crossdisciplinary teams of EIA drafters; authorizing independent reviews of EIA; establishing a separate regulatory unit that demands yearly compliance reports from proponents, displays the results to the public and visits project sites regularly; creating baseline environmental data for the country; enabling proponents to reach out to the closest impacted community; reforming EIA to address local cultural and political structures; and forming a National Accreditation Board would all bolster EIA of SWM projects in Nepal.

\section{Acknowledgments}

Bimal Basnet, Sunil Basnet, Sushma Acharya, Dev Dangi, and Sandesh Dangi were invaluable for their support in the field study. Basant Buddthoki performed additional data collection. The College of Social Sciences Research and Creative Activity Award and Provost's Faculty Scholarship Support Program at Fresno State provided partial funds and release time, respectively, for the lead author. The researchers would like to thank Hari Dangi for offering ground transportation and Puran Thapa for providing housing during the field study in Nepal. Also, special thanks are due to the Okharpauwa and Chhatre Deurali residents who took part in the survey, the interviewees, and the focus group participants.

\section{References}

ADB, \& ICIMOD. (2006). Environmental assessment of Nepal: Emerging issues and challenges. Kathmandu: ADB.

Ahmad, B., \& Wood, C. (2002). A comparative evaluation of the EIA systems in Egypt, Turkey and Tunisia. Environmental Impact Assessment Review, 22, 213-234.

Anneveldt, E., \& Pasman, M. (2001). Country status report Nepal: A national case study on the integration of biodiversity into EIA. Kathmandu: UNEP/UNDP/GEF.

Anonymous. (2010). July 20. Personal communication.

Appiah-Opoku, S., \& Bryan, H. C. (2013). EA follow-up in the Ghanaian mining sector: challenges and opportunities. Environmental Impact Assessment Review,

$41,38-44$

Bartlett, R. V., \& Baber, W. F. (1989). Bureaucracy or analysis: implications of impact assessment for public administration. In R. V. Bartlett (Ed.), Policy through impact assessment (pp. 143-153). New York: Greenwood Press.

Belbase, N. (2003). Environmental impact assessment: Thoughts from Nepal. Kathmandu: No Publisher.

Bhatt, R. P., \& Khanal, S. N. (2009). Environmental impact assessment system in Nepal - an overview of policy, legal instruments and process. Kathmandu University Journal of Science, Engineering and Technology, 5(II), 160-170.

Bhatt, R. P., \& Khanal, S. N. (2010). Environmental impact assessment system and process: a study on policy and legal instruments in Nepal. African Journal of Environmental Science and Technology, 4(9), 58-94.

Brown, D., \& Jacobs, P. (1996). Adapting environmental impact assessment to sustain the community development process. Habitat International, 20(3) 493-507.

Clausen, A., Vu, H. H., \& Pedrono, M. (2011). An evaluation of the environmenta impact assessment system in Vietnam: the gap between theory and practice. Environmental Impact Assessment Review, 31, 136-143. 
Dangi, M. B. (2009). Solid waste management in Kathmandu, Nepal: The anatomy of persistent failure. Published Doctoral Dissertation, the Johns Hopkins University, Baltimore. Ann Arbor: ProQuest LLC.

Dangi, M. B., Pretz, C. R., Urynowicz, M. A., Gerow, K. G., \& Reddy, J. M. (2011) Municipal solid waste generation in Kathmandu, Nepal. Journal of Environmental Management, 92, 240-249.

Dangi, M. B., Urynowicz, M. A., \& Belbase, S. (2013). Characterization, generation, and management of household solid waste in Tulsipur, Nepal. Habitat International, 40, 65-72.

Dangi, M. B., Urynowicz, M. A., Gerow, K. G., \& Thapa, R. B. (2008). Use of stratified cluster sampling for efficient estimation of solid waste generation at household level. Waste Management \& Research, 26, 493-499.

ERMC (P.) Ltd., C-CON (P.) Ltd., \& Masina Continental Associates (P.) Ltd. (2005). National environmental impact assessment (EIA) guidelines for solid waste management project in the municipalities of Nepal. Lalitpur: MLD.

GEOCE Consultants (P.) Ltd. (2009). Environmental impact assessment study of Banchare danda long term landfill site. Lalitpur: MLD.

INECE. (2013). Environmental impact assessment. Washington, D.C.: INECE. http:// nece.org/EIA/5FAQS.htm Accessed 16.09.10.

Joshi, M. (2010). July 7. Personal communication.

Khadka, R. B. (2010). July 9. Personal communication.

Khadka, R. B., \& Shrestha, U. S. (2005). IEE of proposed sanitary landfill site of Tribhuwan Nagar municipality. Kathmandu: SchEMS.

Leu, W. S., Williams, W. P., \& Bark, A. W. (1997). Evaluation of environmental impact assessment in three Southeast Asian nations. Project Appraisal, 12(2), 89-100.

Li, J. C. (2008). Environmental impact assessments in developing countries: An opportunity for greater environmental security?. USAID Working Paper No. 4. Falls Church: FESS.

Li, T. H. Y., Ng, S. T., \& Skitmore, M. (2012). Public participation in infrastructure and construction projects in China: from an EIA-based to a whole-cycle process. Habitat International, 36, 47-56.

Lo, C. W. H., Yip, P. K. T., \& Cheung, K. C. (2000). The regulatory style of environmental governance in China: the case of EIA regulation in Shanghai. Public Administration and Development, 20, 305-318.

Maharjan, R. S. (2010). July 8. Personal communication.

Manandhar, B. R. (2010a). July 7. Personal communication.

Manandhar, R. (2010b). July 21. Personal communication.
Momtaz, S. (2002). Environmental impact assessment in Bangladesh: a critical review. Environmental Impact Assessment Review, 22, 163-179.

Morgan, R. K. (2012). Environmental impact assessment: the state of the art. Impact Assessment and Project Appraisal, 30(1), 5-14.

MOSTE. (2013). List of approved EIAs. Kathmandu: Government of Nepal.

Nadeem, O., \& Hameed, R. (2010). Exploring the potential and constraints to implementing the international best practice principles of EIA follow-up: the case of Pakistan. Journal of American Science, 6(12), 108-121.

NCSIP. (1994). Environmental impact assessment guidelines 1993. Kathmandu: NPC IUCN.

NESS. (2001). Environmental impact assessment for solid waste treatment plant and development of sanitary landfill site at Simdol-ko-gairo, Okharpauwa VDC, Nuwakot. Lalitpur: MLD.

Nippon Koei Co. Ltd., \& Yachiyo Engineering Co. Ltd. (2004). The study on the solid waste management for the Kathmandu Valley. Interim report (1). Kathmandu: JICA.

Obbard, J. P., Lai, Y. C., \& Briffett, C. (2002). Environmental assessment in Vietnam: theory and practice. Journal of Environmental Assessment Policy and Management, 4(3), 267-295.

Oli, D. B. (2010). July 8. Personal communication.

Ortolano, L., Jenkins, B., \& Abracosa, R. (1987). Speculations on when and why EIA is effective. Environmental Impact Assessment Review, 7, 285-292.

Panigrahi, J. K., \& Amirapu, S. (2012). An assessment of EIA system in India. Environmental Impact Assessment Review, 35, 23-36.

Tan, A. K. J. (2004). Environmental laws and institutions in Southeast Asia: a review of recent developments. Singapore Yearbook of International Law, 8, 177-192.

UNESCAP. (2003). Nepal: Policies, laws, guidelines, standards and international obligations related to EIA implementation. Bangkok: United Nations.

Uprety, B. K. (2003). Environmental impact assessment: Process and practice. Kathmandu: Uttara Uprety.

Uprety, B. K. (2007). A decade of legally practicing the environmental assessment tool. Kathmandu: MOEST.

Wood, C. (2003). Environmental impact assessment: A comparative review (2nd ed.). Harlow: Pearson.

Zubair, L. (2001). Challenges for environmental impact assessment in Sri Lanka. Environmental Impact Assessment Review, 21, 469-478. 


\section{Appendix. Sample survey questionnaire (translated from Nepali)}

How long have you been staying here?

What is your household's monthly income in Nepalese Rupee (NR)?

a) Below NR 1,000

b) NR 1,000-5,000

c) NR $5,001-10,000$

d) Above NR 10,000

e) Other, please specify.

How many people live in your household?

Adults, Children, Total

Please tell me the level of education and type of profession of your family/family members below. (Provide the same for other family members in the household.)

Your Education, Your Profession Spouse's Education, Spouse's Profession

Please tell me if you own land.

Yes ___ No ___ If yes, can you tell me how much land do you own?

When did you first learn about the Banchare Danda landfill site (BLS)?

From the list below, please tell me how you learned about the BLS.

(Please mark all that apply.)

Print media.

Public notices.

Pamphlets and informative brochures.

Exhibitions and project information center displays.

Newsletters.

Radio and television announcements.

Electronic mail/web sites.

Other, please specify.

If you marked any of the options above in question 7 , did the announcement describe the proposal of the planned BLS?

Yes No

Were you made aware of any background information such as why this site was chosen and any environmental, economic or social impacts about the site?

Yes ___ No___ If yes, what were they?

Yes_ No_ Was the information you received accurate?

Yes_ No Wa Was the information easy to understand?

Did you know about the size and period BLS will be active?

Yes No If yes, how did you learn about it?

Yes No was the information you received accurate?

Yes _ No _ was the information easy to understand?

Did you voice any concerns during the public comment period?

Yes __ No __ if yes, was there any response from the responsible authority?

Did you attend any public meetings, group discussions, workshops or participate in any interviews that solicited your opinions or concerns and suggestions?

Yes No If yes, what were they?

Were you aware of any development work that were to be done in conjunction with the BLS such as construction of roads, bridges, schools, hospitals or any others? 
Yes No If yes, what were they?

If you answered yes to question 13 above, was the information you received about improvements accurate?

Yes No

Have any development works committed to your community been completed?

Yes No If yes, what were they?

Describe any impacts BLS or temporary landfill sites have had to you or your property. Were you reimbursed for any land or other property by the government?

Yes No if yes, are you satisfied with the amount you received?

Were you promised employment, training on skill development or educational benefits from the government?

Yes No If yes, what were they?

Are you satisfied with the actions of government services connected to the BLS and/or other temporary landfill sites?

Yes No Do you have any additional comments in this topic?

Did you learn about any alternate locations being considered for BLS?

Yes No If yes, what were they?

If you attended a public meeting called for BLS or one of the temporary landfill sites, please check all that apply to you.

Was it located in a convenient public place?

Did it begin with a description of the proposal and its anticipated effects?

Were there displays of posters or other illustrative material?

Were the potential negative and positive impacts covered in a clear and understandable way?

Were concerned people invited to identify the issues and alternatives that they believed should be addressed?

Were speakers given adequate time in which to comment?

Did speakers restrict their comments to the identification of major issues and possible alternatives to the proposed action?

Other, please specify.

Are you aware of any additional meetings that were held during the development phase of BLS or other temporary landfills?

Yes No if yes, please describe them.

Are you aware of any public telephone, "hot line", which enabled citizens to call and ask questions or to make comments about the proposal?

Yes No If yes, have you used it?

If yes, how did you hear about it? (Mark all that apply.)

Announcements on television/radio programs.

Announcement in newspaper.

In brochures from Kathmandu Metropolitan City.

In brochures from Ministry of Local Development.

Other, please specify.

If you used a public telephone, "hot line", please mark all that apply.

Was the person answering the phone:

Knowledgeable about the project? 
Knowledgeable about relevant government rules and regulations?

Polite, friendly, non-threatening, and informative (but non-technical)?

Are you aware of any public survey questionnaires used?

Yes No If yes, did you participate in the survey?

If you participated in the survey, were you informed of any of the following?

(Please mark all that apply to you.)

How the information would be used.

Who or what kinds of people are being interviewed.

How long the survey will take to complete.

How individual confidentiality would be kept.

What is your level of satisfaction for the public participation conducted for the BLS?

Very happy.

Happy.

Neutral.

Unhappy.

Very unhappy.

Do you believe the BLS will be open within the next:

$0-6$ months.

6-12 months.

12-24 months.

$2-5$ years.

Other, please specify.

Are you satisfied with the results of the EIA process?

Very happy.

Happy.

Neutral.

Unhappy.

Very unhappy.

Are you satisfied with the operation of the temporary landfill site?

Very happy.

Happy.

Neutral.

Unhappy.

Very unhappy.

Are you satisfied with the proposed buffer zone of $300 \mathrm{~m}$ around the BLS?

Yes No 